\title{
ANALISIS PENGARUH KOMPENSASI DAN KEPUASAN KERJA TERHADAP PRODUKTIVITAS KERJA WIRANIAGA SUZUKI PT RESTU MAHKOTA KARYA JAKARTA
}

\author{
Enny Ariyanto ${ }^{1)}$ \\ Gazali Rahman $^{2}$ \\ 1)Program Studi S2 Manajemen Pascasarjana Universitas Mercu Buana \\ e-mail: eny_ariyanto@yahoo.com \\ ${ }^{2)}$ Program Studi S2 Manajemen Pascasarjana Universitas Mercu Buana \\ e-mail: rahman.gazali@gmail.com
}

\begin{abstract}
This study aims to examine the effect of compensation and job satisfaction on the labor productivity of Suzuki car salesman at PT Restu Mahkota Karya. The study sample involves 162 respondents of six personal salers from different areas and is determined through saturation sampling technique. Primary data is obtained through a questionnaire. Multiple linear regression model is used to test the hypothesis of the influence of variable compensation and job satisfaction on productivity. The research proves that the variable compensation partially has no significant effect on the productivity of the sales force. However, the variable of job satisfaction has weak significant influence on the productivity of the sales force. Furthermore, simultaneous variable compensation and job satisfaction have weak significant positive effect on the productivity of the sales force of PT Restu Mahkota Karya.
\end{abstract}

Keywords: compensation, job satisfaction, productivity, sales force

\section{PENDAHULUAN}

Dengan membaiknya perekonomian Indonesia beberapa tahun terakhir telah menempatkannya sebagai negara pasar mobil dengan pangsa terbesar kedua setelah Thailand di kawasan Asean. Data pemasaran mobil di Indonesia, sebagaimana dirilis oleh Gabungan Industri Kendaraan Bermotor Indonesia (Gaikindo) menunjukkan total penjualan mobil dari distributor ke dealer (wholesaler) seluruh Indonesia selama tahun 2012 adalah mencapai 1.116.402 unit, yaitu mengalami peningkatan sebesar 24,8 persen dibanding tahun 2011. Angka pertumbuhan penjualan tersebut diperkirakan masih akan meningkat hingga 10 persen pada tahun 2013. Kenaikan angka penjualan dialami oleh semua pabrik mobil terutama untuk merek pabrikan Jepang. Merek mobil Honda merupakan produk mobil yang mempunyai pertumbuhan penjualan paling tinggi hingga mencapai 52,6 persen dibanding tahun 2011. Selanjutnya, secara berurutan penjualan ini disusul oleh Mazda sebesar 38,7 persen, Suzuki sebesar 33,8 persen dan Toyota sebesar 30,5 persen.Sedangkan Market share terbesar masih dikuasai mobil Toyota dengan pasar sebesar 36 persen, kemudian Daihatsu 14 persen, Mitsubisi 13 persen, dan Suzuki 11 persen. Kemudian untuk merek mobil lainnya, seperti Honda, Nissan, Isuzu, Mazda baru mampu menguasai market share di bawah 10 persen (Gaikindo, 2013).

PT Suzuki Indomobil Sales, selaku agen tunggal pemegang merek (ATPM) Suzuki di Indonesia bekerja sama dengan seluruh dealernya memasarkan produk mobil keluaran 
Suzuki di Indonesia. Di wilayah Jakarta dan sekitarnya, pada tahun 2012, terdapat sepuluh perusahaan yang menjadi dealer resmi Suzuki. Salah satu di antaranya adalah PT Restu Mahkota Karya, yang mempunyai wilayah pemasaran meliputi Jakarta, Banten dan Jawa Barat. Pesatnya pertumbuhan penjualan mobil memunculkan kompetisi baik sesama dealer suzuki maupun merek lain. Di samping pengembangan fasilitas showroom, penambahan tenaga wiraniaga yang dilakukan selama ini menjadi cara efektif bagi dealer untuk menjaring sebanyak mungkin calon pembeli. Sehingga keberadaan wiraniaga dengan kompetensinya menempati posisi strategis sebagai tenaga penjualan dan ujung tombak pemasaran.

Pengalaman yang dihadapi oleh PT Restu Mahkota Karya selama ini menyajikan fakta bahwa tingginya kebutuhan terhadap jumlah tenaga wiraniaga ternyata tidak sebanding dengan minat pelamar pada pekerjaan tersebut. Hal ini terjadi antara lain karena adanya anggapan sementara pada sebagian masyarakat bahwa pekerjaan wiraniaga belum mampu menjanjikan kehidupan masa depan lebih baik. Kondisi ini tentu membuat pilihan sulit bagi perusahaan untuk mendapatkan calon wiraniaga yang berkualitas. Pada sisi lain tuntutan akan pelayanan terhadap konsumen meningkat, hingga peran dan fungsi wiraniaga tidak lagi terbatas melakukan transaksi penjualan saja tetapi mereka juga dituntut harus mampu memberikan solusi permasalahan bagi pelanggan, menyediakan layanan infomasi, menjelaskan cara penggunaan produk, membantu pelanggan untuk menjual kembali produknya, serta membangun hubungan baik dengan pelanggan (Futrell, 2001). Oleh karena itu, pengetahuan yang memadai mengenai produk perusahaan, pelanggan, pasar, serta keahlian dalam menawarkan merupakan unsur penting yang harus dimiliki seorang wiraniaga (Sutojo, 2008).

Dilihat dari segi pendapatan, profesi wiraniaga merupakan pekerjaan yang paling tinggi tingkat penghasilannya dibandingkan dengan profesi yang setingkat pada posisi tersebut. Namun demikian, tenaga kerja sebagai wiraniaga adalah merupakan jenis profesi yang paling tinggi tingkat turnover tenaga kerjanya. Sebagai contoh, data terdokumentasi jumlah tenaga kerja wiraniaga yang masuk dan keluar di enam lokasi showroom milik PT Restu Mahkota Karya (RKM) periode tahun 2010-2012 seperti nampak pada Tabel 1.

Tabel 1. Profil Perputaran (Turnover) Tenaga Wiraniaga di PT Restu Mahkota Karya Tahun 2010-2012

\begin{tabular}{lcccccc}
\hline \multirow{2}{*}{ Dealer } & \multicolumn{2}{c}{2010} & \multicolumn{2}{c}{ 2011 } & \multicolumn{2}{c}{2012} \\
\cline { 2 - 7 } & Masuk & Keluar & Masuk & Keluar & Masuk & Keluar \\
\hline RMK Kebon Jeruk & 20 & 18 & 36 & 22 & 58 & 32 \\
RMK Roxy & 8 & 5 & 34 & 23 & 30 & 18 \\
RMK Tangerang & 2 & 11 & 14 & 10 & 25 & 45 \\
RMK Cilegon & 2 & 2 & 29 & 13 & 29 & 11 \\
RMK Karawang & 11 & 2 & 18 & 6 & 54 & 17 \\
RMK Depok & 17 & 4 & 34 & 18 & 54 & 34 \\
Jumlah & 60 & 42 & 165 & 92 & 250 & 157 \\
\% Karyawan Keluar/Masuk & 100 & 70,00 & 100 & 55,75 & 100 & 62,80 \\
\hline
\end{tabular}

Sumber data : Departemen SDM PT. RMK, (Januari 2013)

Tabel 1 menunjukkan bahwa selama periode tahun 2010-2012, rerata sebesar 62,85 persen per tahun dari jumlah tenaga wiraniaga yang telah diterima dan telah diberikan 
pembekalan berbagai training pada akhirnya gagal dan berhenti sebagai wiraniaga. Adapun berbagai faktor alasan keluar antara lain adalah karena diberhentikan oleh perusahaan dalam masa percobaan (probation) karena dianggap tidak memenuhi standar minimal untuk dididik sebagai wiraniaga. Ada yang diberhentikan setelah melalui masa percobaan namun tidak mampu mencapai target minimal yang ditetapkan. Ada juga yang keluar karena merasa tidak puas terhadap lingkungan pekerjaanya. Alasan lain adalah karena mendapatkan kesempatan yang lebih baik.

Wiraniaga yang keluar karena faktor ketidakpuasan, manajemen telah mengupayakan untuk menekan (turnover) dengan cara mengurangi sumber-sumber ketidakpuasan. Langkah tersebut diantaranya memberikan sistem point yang berjenjang berdasarkan tingkat kesulitan menjual, yaitu terbagi dalam tiga kelompok meliputi: kelas low difficult, middle difficult, dan high difficult, dengan bobot point masing masing 10, 13 dan 15 poin.

Di samping pemberian bobot yang berbeda juga dibentuk pengelompokan atau leveling wiraniaga berdasarkan tingkat prestasi kemampuan menjual, yaitu kelompok trainee, silver, gold, platinum. Kebijakan pemberian grade pada wiraniaga seperti tersebut berimplikasi terhadap skema kompensasi yang diterima. Secara umum elemen kompensasi finansial terdiri atas gaji pokok, uang makan dan transport, tunjangan grade, tunjangan jabatan, serta insentif penjualan. Kebijakan tersebut diterapkan sejak tahun 2011 dengan tujuan meningkatan produktivitas wiraniaga seiring meningkatnya penjualan mobil secara nasional, dan khususnya di PT RMK sendiri.

Penjualan mobil di PT RMK periode tahun 2010-2012 terus mengalami peningkatan dengan rerata pertumbuhan sebesar 45 persen per tahun, yaitu tahun 2010 tumbuh sebesar 47 persen dari periode tahun sebelumnya, tahun 2011 sebesar 48 persen, dan tahun 2012 sebesar 40 persen. Namun kondisi pertumbuhan penjualan relatif besar tersebut tidak berbanding lurus dengan kenaikan produktivitas tenaga wiraniaganya.

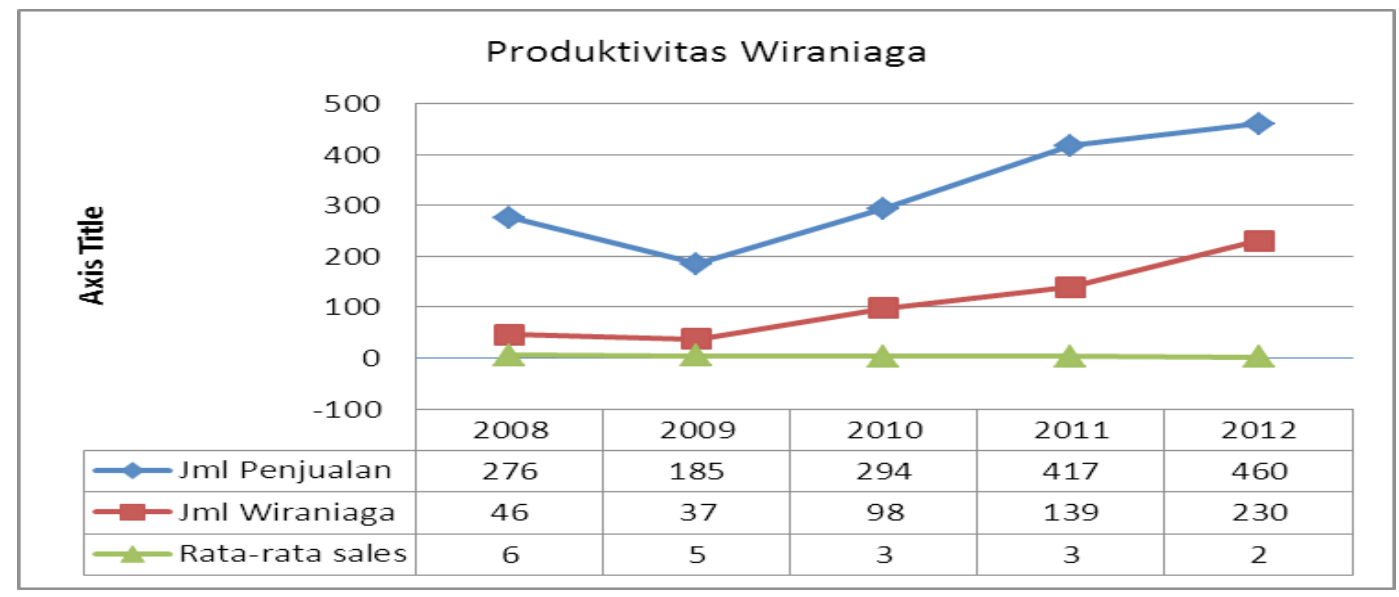

Sumber: Departemen SDM dan Operasional PT.RMK Tahun 2013

Gambar 1. Grafik Rerata Hasil Penjualanper Tenaga Kerja Wiraniaga Tahun 2008-2012

Seperti tampak pada Gambar 1 telah membuktikan bahwa dari enam wilayah showroom PT RMK yang diobservasi sebagai lokasi penelitian menunjukan penambahan jumlah tenaga wiraniaga berbanding positip (searah) dengan peningkatan volume penjualan. Akan tetapi berbanding terbalik dengan perubahan rerata hasil penjualan mobil 
per tahun untuk setiap wiraniaga. Jika pada tahun 2008 setiap tenaga kerja wiraniaga mampu menjual rerata 6 unit mobil, pada periode tahun-tahun berikutnya cenderung menurun, yaitu volume penjualan hanya menjadi rerata 2 unit mobil per tahun untuk setiap tenaga wiraniaga. Hal ini membuktikan bahwa produktivitas rerata per orang wiraniaga dari tahun 2008 sampai dengan tahun 2012 selalu menurun. Hasil wawancara awal penulis (peneliti) terhadap 10 orang tenaga wiraniaga senior, ditemukan beberapa faktor yang diperkirakan menyebabkan menurunnya produktivitas tenaga kerja wiraniaga, antara lain: (a) kualitas SDM rendah sebagai akibat dari pola penarikan (recruitment) tenaga wiraniaga yang dipaksakan untuk memenuhi kuota, (b) adanya keterbatasan perusahaan menyediakan unit produk mobil untuk tipe-tipe tertentu yang dibutuhkan oleh wiraniaga dalam pemenuhan permintaan indent oleh konsumen, (c) kalah bersaing dalam pemberian potongan harga (diskon dimerek mobil lain lebih besar). Hal ini bisa terjadi bila konsumen ternyata mendapatkan harga mobil yang lebih murah di dealer lain karena adanya stock on hand yang siap dibeli.

Selain faktor-faktor tersebut di atas, penurunan rerata produktivitas juga disebabkan oleh adanya beberapa wiraniaga senior di PT RMK yang keluar dan pindah kerja ke dealer mobil merek lain. Kondisi ini menyebabkan terjadinya bongkar pasang pada tim penjualan dan harus mendidik tenaga kerja wiraniaga baru dari awal yang relatif mempunyai kemampuan dan pengalaman kerja menjual mobil lebih rendah.

Berdasarkan uraian fenomena-fenomena fakta seperti di atas maka dapat dirumuskan pertanyaan penelitian sebagai berikut: apakah variabel kompensasi dan kepuasan kerja secara parsial maupun simultan (bersama-sama) berpengaruh terhadap produktivitas kerja wiraniaga Suzuki di PT Restu Mahkota Karya? Selanjutnya, dari pertanyaan penelitian tersebut juga dapat dirumuskan secara ringkas tujuan penelitian, yaitu: untuk membuktikan dan menjelaskan, baik secara parsial maupun simultan, pengaruh variabel kompensasi dan kepuasan terhadap produktivitas kerja wiraniaga Suzuki di PT Restu Mahkota Karya.

\section{Pengaruh Kompensasi terhadap Produktivitas Kerja}

Peran serta para pegawai atau karyawan pada aktivitas produksi perusahaan (organisasi) adalah memberikan sumberdaya jasa yang dimiliki berupa tenaga, pikiran, pengetahuan, dan keahlian-keahlian tertentu untuk sukses proses produksi perusahaan. Dari kontribusi tersebut, kemudian perusahaan akan memberikan kompensasi, yaitu bisa berupa finansial maupun non finansial, sebagai balas jasa atau pembayaran terhadap sumberdaya yang telah diterima perusahaan dari para karyawannya. Tingkat tertentu besaran sumberdaya jasa karyawan yang diberikan ke perusahaan adalah komponen inputoutput yang merepresentasikan prestasi dan produktivitas kerja para karyawan tersebut. Tujuan utama dari pengikatan hubungan kerja ialah karena ada saling ketergantungan antara karyawan yang memberikan pemikiran dan tenaganya kepada perusahaan. Dari tenaga dan pemikiran tersebut perusahaan mendapatkan hasil berupa produk atau jasa yang menghasilkan keuntungan bagi perusahaan. Sebaliknya bagi karyawan akan menerima sejumlah kompensasi. Dengan demikian variabel kompensasi dan produktivitas kerja akan timbul sebagai peristiwa sebab akibat dalam hubungan transaksional antara perusahaan dengan para pegawainya.

Kompensasi adalah merupakan seluruh bentuk imbalan moneter dan non moneter yang diterima karyawan atas hasil kerja karyawan pada perusahaan atau organisasi. Menurut definisi Rivai (2009), definisi kompensasi adalah balas jasa yang diterima karyawan 
sebagai pengganti kontribusi jasa mereka pada perusahaan. Sementara itu, produktivitas kerja didefinisikan sebagai rasio perbandingan antara hasil yang dicapai (output) dan keseluruhan sumberdaya yang digunakan (input). Dalam definisi yang lain menyebutkan bahwa variabel produktivitas dapat dijelaskan melalui dua dimensi, yaitu: (a) dimensi efektivitas, konsep yang mengarah kepada pencapaian target berkaitan dengan kualitas, kuantitas serta waktu; (b). dimensi efisiensi adalah konsep yang berkaitan dengan upaya membandingkan input dengan realisasi pelaksana atau prosesnya (Umar, 2005).

Kompensasi dalam bentuk moneter (finansial) adalah penting bagi karyawan. Karena dengan kompensasi dalam bentuk moneter memiliki tingkat fleksibilitas yang tinggi dan dengan bentuk kompensasi ini para karyawan dapat memenuhi kebutuhannya secara langsung, terutama kebutuhan fisiologisnya.

Dalam kaitannya dengan kompensasi finansial yang terjadi di PT RMK, para karyawan wiraniaga menerima dalam bentuk gaji pokok, tunjangan kesejahteraan serta insentif, dan diterima dalam periode waktu bulanan. Variabel pembayaran gaji mempunyai jaminan relatif lebih pasti, yaitu dalam arti gaji akan tetap dibayarkan tiap bulan walaupun karyawan tersebut tidak masuk bekerja karena alasan yang diperbolehkan. Insentif diartikan sebagai bentuk pembayaran yang dikaitkan dengan kinerja atau produktivitas, yaitu dapat berupa pembagian hasil (gainsharing) sebagai pembagian keuntungan bagi karyawan akibat peningkatan produktivitas atau penghematan biaya (Rivai, 2009). Lebih lanjut Rivai menyebutkan bahwa tujuan utama pemberian insentif sebagai upaya motivasi atau dorongan yang dilakukan manajemen perusahaan kepada para karyawan untuk meningkatkan kualitas dan kuantitas kerjanya. Bagi manajemen organisasi (perusahaan) variabel insentif merupakan strategi untuk meningkatkan produktivitas kerja. Pada situasi perusahaan menghadapi persaingan bisnis yang semakin ketat maka produktivitas kerja menjadi satu hal yang sangat penting untuk meningkatkan daya kompetisinya.

Berkaitan dengan model struktur hubungan antara variabel kompensasi dengan produktivitas kerja, penelitian Black et all (2004) menyimpulkan bahwa produktivitas kerja karyawan meningkat setelah sistem kompenasai berupa pembagian keuntungan diterapkan oleh perusahaan. Pada bagian lain, hasil penelitian Ipkoni (2006) juga membuktikan ada pengaruh bersama positip signifikan variabel kompensasi upah, insentif, tunjangan dan kondisi kerja terhadap kinerja karyawan. Demikian pula temuan penelitian Mustikawati (2006) yang menunjukkan ada pengaruh positip signifikan, baik secara parsial maupun simultan, variabel kompensasi dan motivasi terhadap efektivitas kerja. Selanjutnya, dengan merujuk pada uraian kerangka pemikiran di atas dapat dirumuskan hipotesis sebagai berikut:

$\mathrm{H}_{1}$ : Kompensasi berpengaruh positip dan signifikan terhadap produktivitas kerja wiraniaga Suzuki PT Restu Mahkota Karya.

\section{Pengaruh Kepuasan Kerja terhadap Produktivitas Kerja}

Definisi umum kepuasan kerja ialah pernyataan sikap positip atau negatip tenaga kerja (karyawan) terhadap pekerjaanya. Greenberg dan Baron (2003) mendeskripsikan kepuasaan kerja sebagai sikap positip atau negatip yang dilakukan individu terhadap pekerjaan mereka. Sementara itu, Robbins (2000) menjelaskan bahwa kepuasaan kerja adalah sebagai sikap umum individu pada pekerjaannya, dengan membandingkan selisih antara ganjaran yang diterima dengan yang diyakini seharusnya diterima. Selanjutnya, defenisi kepuasan kerja menurut Mangkunegara (2009) adalah suatu perasaan yang menyokong atau tidak menyokong diri pegawai yang berhubungan dengan pekerjaanya maupun dengan kondisi dirinya. 
Manifestasi sikap positip atau negatip akan timbul berdasarkan penilaian karyawan terhadap situasi kerja (Umam, 2010). Sikap positip tersebut baru akan dirasakan oleh karyawan apabila mereka merasa telah diperlakukan dan diperhatikan secara baik dan adil, kompensasi yang mereka terima sepadan dengan energi yang dikeluarkan, penghargaan dan penghormatan yang mereka terima sepadan dengan pengorbanannya. Jadi, persepsi adil dan proporsional yang membandingkan antara benefit diterima dengan pengorbanan sumberdaya yang mereka berikan akan menentukan sikap positip karyawan pada pekerjaannya. Selanjutnya persepsi konsep tersebut akan berpengaruh terhadap manifestasi perilaku kerja mereka, dan pada akhirnya perilaku kerja para karyawan menentukan kinerjanya.

Produktivitas yang dihasilkan oleh karyawan akan sangat dipengaruhi oleh kepuasan kerja yang mereka dapatkan. Karyawan yang merasa puas cenderung bekerja lebih giat dan lebih semangat. Sebaliknya bila kepuasan dalam bekerja tidak mereka dapatkan maka akan terjadi banyak penundaan bekerja yang berakibat pada menurunnya produktivitas. Penelitian Naibaho (2008) membuktikan bahwa kepuasan kerja berpengaruh positip signifikan terhadap produktivitas kerja. Serupa dengan hasil penelitian Naibaho adalah penelitian Ekonugroho (2008) juga membuktikan kepuasan kerja berpengaruh positip signifikan terhadap produktivitas kerja. Pada kesimpulan penelitian yang sama adalah penelitian Almigo (2004) dan Alfaidah (2007) juga membuktikan bahwa kepuasan kerja berpengaruh positif signifikan terhadap produktivitas kerja karyawan. Dengan demikian dapat dirumuskan hipotesis sebagai berikut:

$\mathrm{H}_{2}$ : Kepuasan kerja berpengaruh positip dan signifikan terhadap produktivititas kerja wiraniaga Suzuki PT Restu Mahkota Karya

\section{Pengaruh Kompensasi dan Kepuasan Kerja terhadap Produktivitas Kerja}

Dewan Produktivitas Nasional mendefenisikan produktivitas sebagai perbandingan antara hasil yang dicapai (output) dengan keseluruhan sumber daya yang digunakan (input). Dengan menggunakan dua dimensi variable produktivitas, yaitu: (a) dimensi efektivitas adalah konsep yang mengarah kepada pencapaian target berkaitan dengan kualitas, kuantitas serta waktu; (b) dimensi efisiensi adalah konsep yang berkaitan dengan upaya membandingkan input dengan realisasi pelaksana atau prosesnya (Umar, 2005).

Produktivitas dipengaruhi oleh faktor-faktor: kemampuan, kecakapan yang dimiliki berdasarkan pengetahuan, lingkungan kerja yang menyenangkan (Hariandja, 2002). Sedarmayanti (2001) menyebutkan ada enam faktor utama yang menentukan produktivitas karyawan, yaitu: sikap kerja, tingkat keterampilan, hubungan kerja, manajemen produktivitas, efisien tenaga kerja, serta kewirausahaan.

Pengukuran produktivitas berkorelasi tinggi dengan penilaian kinerja yang berpengaruh pada kepuasan kerja serta kompensasi. Indikator yang dapat digunakan dalam mengukur produktivitas meliputi kuantitas kerja, kualitas kerja, serta ketepatan waktu (Simamora, 2004). Penilaian produktivitas dapat digunakan sebagai atribut penilaian kinerja karyawan. Sinungan (2005) menguraikan bahwa manfaat dari pengukuran produktivitas kerja adalah sebagai umpan balik pelaksanaan kerja, sebagai dasar pemberian penghargaan prestasi, mendeteksi penyimpangan rencana, kesesuaian penempatan karyawan (staffing).

Naibaho (2008) dalam penelitianya membuktikan, baik secara simultan maupun parsial, kompensasi dan kepuasan kerja berpengaruh positip signifikan terhadap 
produktivitas kerja. Secara simultan dua variabel prediktor terebut (kompensasi dan kepuasan kerja) mempunyai koefisien determinasi 42,8 persen terhadap variasi produktivitas kerja karyawan. Pada variabel kompensasi, hasil penelitian Rapang (2005) membuktikan bahwa kompensasi berpengaruh positip signifikan kuat terhadap produktivitas kerja karyawan, dan mempunyai koefisien determinasi sebesar 50,41 persen. Penelitian Setiadi (2009) juga membuktikan variabel kepuasan kerja berpengaruh positip signifikan terhadap produktivitas kerja karyawan. Pada akhirnya dengan merujuk pada beberapa referensi di atas, dapat dirumuskan hipotesis sebagai berikut:

$\mathrm{H}_{3}$ : Kompensasi dan kepuasan kerja secara simultan berpengaruh positip signifikan terhadap produktivitas wiraniaga Suzuki PT Restu Mahkota Karya.

\section{METODE PENELITIAN}

Populasi dalam penelitian ini melibatkan seluruh karyawan wiraniaga yang telah bekerja sekurang-kurang selama enam bulan di PT Restu Mahkota Karya dari enam kantor wilayah showroom, yaitu Cilegon, Cimone (Tangerang), Cimanggis (Depok), Roxy (Jakarta Pusat), Kebon Jeruk (Jakarta Barat), dan Karawang (Jawa Barat). Dari definisi tersebut maka didapat populasi berukuran 162 orang karyawan, dan semua anggota populasi ditetapkan sebagai sampel atau responden penelitian. Oleh karena itu teknik pengambilan sampel adalah sistem sensus atau saturation sampling.

Pendekatan penelitian adalah metode survei. Koleksi data dalam penelitian ini melibatkan semua anggota sampel sebagai subjek penelitian, dan menggunakan instrumen angket (kuesioner) dalam koleksi data primer. Desain penelitian adalah model relasi (hubungan) kausalitas, yaitu mempelajari hubungan atau pengaruh variabel kompensasi dan kepuasan kerja terhadap produktivitas karyawan wiraniaga. Derajat hubungan variabel tersebut dinyatakan dalam koefesien korelasi yang digunakan untuk menguji atau mengukur kuat lemahnya hubungan kausalitas variabel dalam struktur model penelitian. Adapun teknik penelitian yang digunakan untuk menguji (verifikasi) rumusan hipotesis ialah teknik regresi linier berganda (multiple linear regression).

Data primer hasil pengukuran persepsi responden bersifat kualitatif. Untuk memperoleh data primer tersebut, variabel kompensasi diukur melalui empat dimensi, berupa: gaji, tunjangan, insentif, dan kompensasi tidak langsung (Rivai, 2009). Pengukurannya menggunakan 14 item kuesioner. Variabel kepuasan kerja diukur melalui enam dimensi meliputi dimensi: isi pekerjaan (job content), pengawasan (supervision), organisasi dan manajemen, kesempatan maju, rekan kerja, kondisi kerja (working condition), serta fasilitas kerja (Rivai, 2009). Pengukurannya menggunakan 16 item kuesioner. Selanjutnya variabel produktivitas diukur melalui delapan dimensi yaitu: tanggung jawab, keterampilan, disiplin, pengetahuan, inovatif, keinginan belajar, kerukunan kerja, sistem dan teknologi Sedarmayanti (2001). Dimensi ini diukur melalui 9 item kuesioner.

Data persepsi hasil pengukuran pada masing-masing variabel penelitian bersifat kualitatif berskala Likert dengan empat peringkat opsi. Jawaban setiap item mempunyai gradasi tertinggi skor 4 dan terendah skor 1 . Alternatif jawaban atau pernyataan dibuat dalam bentuk check box. Hal ini bertujuan untuk mempertajam penggalian informasi yang ingin diserap dari para responden. 


\section{HASIL PENELITIAN DAN PEMBAHASAN}

\section{Karakteristik Responden}

Data hasil pengukuran melalui kuesioner yang diberikan kepada 162 karyawan wiraniaga PT Restu Mahkota Karya sebagai responden, mempunyai karakteristik sebagai berikut: menurut jenis kelamin menunjukkan responden wanita sebanyak 11 persen dan pria 89 persen. Ini mengarahkan pendapat bahwa pekerjaan wiraniaga di PT RMK lebih didominasi oleh kaum pria karena alasan tingkat mobilitas lebih tinggi dibandingkan kaum wanita.

Karekteristik kedua berdasarkan usia, yaitu: tidak ada responden yang berusia dibawah 20 tahun. Hal ini mengingat tingkat tanggung jawab sebagai wiraniaga mobil begitu besar belum tepat dipercayakan kepada mereka yang masih yunior dan baru lulus sekolah setingkat SMU. Responden berusia antara 20-25 tahun sebanyak 18,50 persen. Kemudian pada rentang usia antara 26-30 tahun 31,50 persen, dan yang telah berusia sama atau diatas 31 tahun sebanyak 50 persen.

Selanjutnya distribusi responden berdasarkan tingkat pendidikan terakhir dimiliki, yaitu: sebanyak 51,20 persen responden adalah lulusan SMU sederajat, kemudian lulusan diploma sebanyak 19,10 persen, dan lulusan sarjana sebanyak 29 persen, serta terdapat lulusan magister 0,60 persen. Lulusan SMU sederajat lebih mendominasi pekerjaan ini karena perusahaan kesulitan untuk menjaring lulusan minimal setingkat diploma, karena kebijakan perusahaan juga tidak memberikan kompensasi yang lebih atau berbeda berdasarkan latar belakang pendidikan.

Terakhir, distribusi responden berdasarkan karakteristik level atau grade. Berdasarkan jenjang karir, responden dalam penelitian ini tidak melibatkan karyawan wiraniaga yang masih dalam masa percobaan atau status trainee. Responden yang dilibatkan dalam penelitian ini mulai dari level silver sebanyak 79 persen (kemampuan wiraniaga minimal menjual rata rata 3 unit perbulan). Kemudian level gold 12,30 persen (kemampuan menjual rata-rata perbulan diatas 6 unit). Responden yang menduduki jabatan sales coordinator sebanyak 8,60 persen.

\section{Hasil Uji Validitas dan Reliabilitas Instrumen Penelitian}

Pegujian validitas instrumen penelitian dilakukan dengan metode Corrected item Total Correlation, yaitu dengan cara mengkorelasikan masing-masing skor item dengan skor total item dan melakukan koreksi terhadap efek spurious overlap (nilai koefesien korelasi yang overestimasi). Hasil pengujian dengan perhitungan $r_{\text {hitung }}$ item 1 sampai item 14 terlihat bahwa semua item kuesioner adalah valid karena nilai Corrected Item Total Correlation melebihi nilai $r_{\text {tabel }}$ sebesar 0,152. Kemudian pada variabel kepuasan kerja, terdapat satu item yang tidak valid karena memiliki koefesien $r_{\text {hitung }}-0,094$, atau di bawah $r$ tabel 0,152 , sehingga item tersebut harus dikeluarkan. Selanjutnya pada variabel produktivitas semua item valid karena koefisien $r_{\text {hitung }}$ di antara $0,278-0,595$, ialah semua koefesien $\mathrm{r}_{\text {hitung }}$ bernilai di atas $\mathrm{r}$ tabel $(>0,152)$.

Hasil uji reliabilitas variabel kompensasi menghasilkan koefisien Cronbach's alpha 0,838 , variabel kepuasan kerja mempunyai koefisien Cronbach's alpha 0,841. Variabel produktivitas Cronbach's alpha sebesar 0,760. Hasil print out perhitungan dengan SPSS, diperoleh koefisien Cronbach'c Alpha masing-masing variabel penelitian menunjukkan koefisien terendah pada variabel produktivitas kerja $(0,760)$ dan teringgi variabel kepuasan kerja (0,841). Dengan mengacu pada koefisien minimal 0,6 (Nunully, 1978 
dalam Ghozali,2005) sebagai batas terendah (cut off) maka nilai reliabilitas instrumen pada semua variabel penelitian layak dan masuk dalam kriteria reliabel.

Tabel 2. Uji Reliabilitas

\begin{tabular}{|c|c|c|c|}
\hline Variabel & Cronbach Alpha & $\mathrm{r}$ cut off & Kesimpulan \\
\hline Kompensasi & 0.838 & 0.7 & Reliabel \\
\hline Kepuasan Kerja & 0.841 & 0.7 & Reliabel \\
\hline Produktivitas & 0.760 & 0.7 & Reliabel \\
\hline
\end{tabular}

Sumber : Data primer yang diolah, 2013

\section{Analisis Regresi Linier Berganda}

Analisis regresi linier berganda digunakan untuk mengetahui pengaruh variabel kompensasi dan kepuasan kerja terhadap produktivitas kerja karyawan, yaitu diketahui melalui besaran koefisien estimasi parameter regresi $(=\beta)$ hasil perhitungan. Adapun perhitungan koefisien regresi linier berganda dilakukan dengan bantuan program SPSS yang secara lengkap dapat dilihat pada output hasil print out komputer seperti nampak pada Tabel 3.

Tabel 3. Koefisien Regresi Hasil Output Pengolahan Data dengan Program SPSS 19

Coefficients $^{\mathrm{a}}$

\begin{tabular}{|c|c|c|c|c|c|}
\hline \multirow[t]{2}{*}{ Model } & $\begin{array}{r}\text { Unsta } \\
\text { Coe }\end{array}$ & $\begin{array}{l}\text { dardized } \\
\text { ficients }\end{array}$ & $\begin{array}{l}\text { Standardized } \\
\text { Coefficients }\end{array}$ & \multirow[t]{2}{*}{$\mathrm{t}$} & \multirow[t]{2}{*}{ Sig. } \\
\hline & & Std. Error & Beta & & \\
\hline (Constant) & 2.731 & .182 & & 15.002 & .000 \\
\hline kompensasi & -.144 & .084 & -.169 & -1.723 & .087 \\
\hline $\begin{array}{l}\text { kepuasan } \\
\text { kerja }\end{array}$ & .222 & .079 & .274 & 2.795 & .006 \\
\hline
\end{tabular}

a. Dependent Variable: Produktivitas

Dengan merujuk pada Tabel 3 dapat disusun persamaan regresi linier berganda sebagai berikut:

\begin{tabular}{llcc}
\hline \multicolumn{3}{l}{ Produktivitas $=2,731$} & $-0,144$ Kompensasi $+0,222$ Kepuasan \\
\hline $\mathrm{SE}$ & $(0,182)$ & $(0,084)$ & $(0,079)$ \\
$\mathrm{t}_{\text {hitung }}$ & 15,002 & $-1,723$ & 2,795 \\
$\mathrm{Sig}$ & 0,000 & 0,087 & 0,006 \\
\hline
\end{tabular}

Persamaan regresi linier berganda di atas menunjukkan bahwa koefisien $b_{1}=-, 144$, adalah negatif dan tidak signifikan $\left(\mathrm{t}_{\mathrm{h}}=1,723\right.$; sig. $\left.=0,087\right)$. Kesimpulan: hipotesis pertama $\left(\mathrm{H}_{1}\right)$ ditolak, $\mathrm{H}_{0}$ diterima. Artinya tidak ada pengaruh variabel kompensasi terhadap produktivitas kerja wiraniaga Suzuki PT RMK. Koefisien $b_{2}=0,222$ adalah positip signifikan $\left(t_{h}=2,795\right.$; sig. $\left.=0,006\right)$. Kesimpulan: hipotesis kedua $\left(\mathrm{H}_{2}\right)$ diterima 
(terbukti), $\mathrm{H}_{0}$ ditolak. Artinya ada pengaruh positip signifikan kepuasan kerja terhadap produktivitas kerja wiraniaga.

Hasil penelitian menunjukan bahwa kompensasi tidak memberikan pengaruh secara positip terhadap peningkatan produktivitas terutama pada dimensi gaji dan tunjangan yang bersifat tetap. Kecuali pada dimensi insentif yang bersifat fluktuatif masih berkorelasi positip (tetapi lemah) dengan dimensi inovasi pada variabel produktivitas. Artinya bagi para wiraniaga dapat termotivasi untuk meningkatkan produktivitas kerjanya, yaitu dengan memberdayakan kemampuan menjual sebaik mungkin karena mengharapkan penghasilan berupa insentif yang bersifat fluktuatif. Tinggi rendahnya penjualan mobil ternyata tidak semata dipengaruhi oleh skema atau struktur kompensasi yang diberikan kepada wiraniaganya. Namun sangat dipengaruhi oleh faktor eksternal seperti kemampuan daya beli konsumen, ketertarikan konsumen pada model tertentu, kemudahan pembiayaan dari perbankan atau regulasi pemerintah yang dapat mempermudah atau menghambat pertumbuhan penjualan mobil tersebut.

Variabel kepuasan kerja berpengaruh positip signifikan (pada tingkatan lemah) terhadap produktivitas kerja wiraniaga suzuki di PT RMK. Hal ini menunjukan bahwa kepuasan kerja yang dirasakan oleh para wiraniaga mampu meningkatkan kinerja dan motivasi mereka. Motivasi atau dorongan ini mutlak diperlukan oleh para wiraniaga karena sifat pekerjaan ini berbeda dengan pekerjaan lain. Pekerjaan menjadi wiraniaga harus senantiasa menciptakan kegiatan yang bertujuan mencari calon pembeli, mengolah, hingga menghasilkan terjadi transaksi penjualan. Artinya mereka harus menciptakan pekerjaan mereka sendiri. Sehingga meningkatnya motivasi akan memunculkan kegigihan yang tentunya akan menjadikan produktivitas kerja lebih baik. Kepuasan kerja akan mereka dapatkan bilamana mereka merasa diperlakuan secara baik dan adil oleh perusahaan (tidak dipandang sebelah mata), kemudian diberikan kesempatan maju atau peluang karir secara transparan. Sedangkan dampak negatip bagi perusahaan ketika para wiraniaga tidak mendapatkan kepuasan kerja tentu akan menimbulkan kerugian dengan menurunnya penjualan. Ketidakpuasan kerja bagi wiraniaga akan mereka tunjukkan dengan sikap acuh dan tidak peduli atau bekerja seadanya, karena mengharap perhatian dari perusahaan. Kondisi psikologis yang paling merugikan adalah ketika mereka tidak lagi menaruh harapan pada pekerjaannya. Sehingga mereka bekerja sambil mencari pekerjaan lain yang pada akhirnya mereka akan keluar dan berpindah ke perusahaan lain. Hal ini bila dibiarkan oleh manajemen perusahaan tentunya akan meningkatkan turnover karyawan wiraniaga.

Selanjutnya, hasil dari pembuktian hipotesis ketiga $\left(\mathrm{H}_{3}\right)$, yaitu variabel kompensasi dan variabel kepuasan kerja berpangaruh secara simultan terhadap produktivitas wiraniaga Suzuki PT RMK dapat dijelaskan melalui Tabel 4 dan 5.

Tabel 4. Output Hasil Olah Data dengan Anova Uji F untuk Hipotesis Ketiga

\begin{tabular}{|c|c|c|c|c|c|}
\hline \multicolumn{6}{|c|}{ ANOVA $^{b}$} \\
\hline Model & $\begin{array}{c}\text { Sum of } \\
\text { Squares }\end{array}$ & $\mathrm{df}$ & Mean Square & $\mathrm{F}$ & Sig. \\
\hline 1 Regression & .788 & 2 & .394 & 3.905 & $.022^{\mathrm{a}}$ \\
\hline Residual & 16.035 & 159 & .101 & & \\
\hline Total & 16.823 & 161 & & & \\
\hline
\end{tabular}

a. Predictors: (Constant), kepuasan kerja, kompensasi

b. Dependent Variable: Produktivitas 
Tabel 5. Output Hasil Olah Data untuk Koefisien R, R², dan Adjusted R Model Summary

\begin{tabular}{|c|c|c|c|c|}
\hline Model & $\mathrm{R}$ & $\mathrm{R}$ Square & $\begin{array}{c}\text { Adjusted R } \\
\text { Square }\end{array}$ & Std. Error of the Estimate \\
\hline Dimension 01 & $.216^{\mathrm{a}}$ & .047 & .035 & .31757 \\
\hline
\end{tabular}

a. Predictors: (Constant), Kepuasan Kerja, Kompensasi

Dari output hasil olah data dengan analisis varian (ANOVA), seperti tertera pada Tabel 4, membuktikan kebenaran hipotesis ketiga $\left(\mathrm{H}_{3}\right)$ yaitu bahwa secara simultan variabel kompensasi dan kepuasan kerja berpengaruh secara positif dan signifikan terhadap produktivitas kerja para wiraniaga suzuki PT. RMK $\left(\mathrm{F}_{\text {hitung }}=3,965 ; \mathrm{Sig}=0,022\right)$. Hasil analisis determinasi menunjukan besaran angka $\mathrm{R}$ Square adalah 0,047. Hal ini menunjukan bahwa persentase sumbangan pengaruh kompensasi dan kepuasan kerja terhadap produktivitas kerja para wiraniaga Suzuki di PT Restu Mahkota Karya secara bersama-sama hanya sebesar 4,7 persen. Sedangkan sisanya (90,53 persen) dipengaruhi oleh banyak variabel lain yang tidak dimasukan dalam model penelitian ini. Koefisien determinasi sangat kecil atau kurang dari 5 persen, membuktikan bahwa dua variabel prediktor kompensasi dan kepuasan kerja tidak bisa diandalkan untuk menciptakan kinerja produktif karyawan wiraniaga di PT RMK.Karena itu manajemen perusahan harus melihat faktor-faktor lain yang dapat dipakai secara maksimal untuk membangun kinerja karyawan wiraniaga.

Sejalan dengan teori kepuasaan yang dikemukakan oleh Fredrick Herzberg, bahwa terdapat dua hal yang mempengaruhi sikap seseorang terhadap pekerjaanya. Yang pertama ialah maintenance factor, di mana bila faktor ini dihilangkan akan menimbulkan ketidakpuasan bagi pekerja. Keberadaan faktor ini juga tidak mampu menambah kepuasan kerja. Dalam penelitian ini faktor-faktor dimaksud antara lain adalah kebijakan perusahaan, supervisi, hubungan interpersonal, lingkungan kerja, dan gaji. Faktorfaktor tersebut keberadaanya tidak akan berpengaruh langsung terhadap peningkatan produktivitas kerja wiraniaga, namun bila tidak diperhatikan atau bahkan dikurangi maka dapat dipastikan akan berpengaruh negatip terhadap produktivitas kerja wiraniaga.

Yang kedua adalah disebut satisfier factor, yaitu faktor motivasi. Keberadaan variabel motivasi mampu meningkatkan kepuasan kerja, namun tidak berpengaruh pada ketidakpuasaan. Terkait dengan faktor ini, yaitu yang dapat meningkatkan kepuasan kerja para wiraniaga, bila mereka diberikan pengakuan atas prestasi pencapaian penjualan, mesti diberikan kenaikan pangkat atau level posisi karir lebih tinggi. Pemberian tugas yang lebih menantang, seperti dalam bentuk pemberian tanggung jawab dalam memimpin tim, akan membangun rasa percaya diri dan peran penting dalam tugasnya sebagai wiraniaga. Faktor-faktor tersebut dapat menimbulkan kepuasan dan motivasi kerja para wiraniaga yaitu untuk berprestasi melalui usaha meningkatkan penjualan.

\section{KESIMPULAN}

Berdasarkan hasil analisis yang telah diuraikan di atas, maka dapat ditarik beberapa kesimpulan sebagai berikut:

1. Kompensasi secara parsial tidak berpengaruh signifikan terhadap produktivitas kerja para wiraniaga Suzuki di PT Restu Mahkota Karya. Variabel kompensasi melalui dimensi gaji pokok, tunjangan jabatan dan tunjangan grading, faktor insentif 
serta tunjangan finansial tidak langsung yang diberikan perusahaan belum mampu memberikan pengaruh positip berprestasi terhadap peningkatan produktivitas kerja wiraniaga. Hanya faktor insentif yang berkorelasi positip, tetapi pada level lemah, dengan dimensi perilaku inovatif pada variabel produktivitas kerja. Artinya insentif mampu memberikan pengaruh positip terhadap sikap inovatif para wiraniaga untuk lebih berkreasi dalam upaya meningkatkan penjulaan .

2. Kepuasan kerja secara parsial berpengaruh signifikan lemah terhadap produktivitas kerja wiraniaga Suzuki PT RMK. Dari analisis penelitian didapat tiga dimensi variabel kepuasan yang berpengaruh terhadap produktivitas kerja wiraniaga, yaitu: model pengawasan, peluang karir dan peran rekan sekerja. Model pengawasan yang baik berkorelasi terhadap produktivitas ketika wiraniaga merasa diberikan kepercayaan penuh untuk mewakili perusahaan berhadapan dengan konsumen. Peluang karir berkorelasi terhadap peningkatan penjulaan ketika mereka percaya bahwa salah satu pertimbangan peningkatan karir adalah dengan mempertimbangkan hasil penjualan mereka. Selanjutnya dimensi rekan sekerja berkorelasi dengan produktivitas bilamana terjalin hubungan yang harmonis dan kerja sama yang baik di antara para wiraniaga di tengah persaingan dan konflik yang sering muncul dalam keseharian tugas mereka.

3. Kompensasi dan kepuasan kerja secara simultan berpangaruh signifikan lemah terhadap produktivitas wiraniaga suzuki di PT RMK. Besaran koefisien determinasi kurang dari 5 persen. Hal ini menyimpulkan bahwa peningkatan produktivitas kerja para wiraniaga yaitu berupa besaran unit penjualan mobil sangat ditentukan oleh variabel-variabel lain di luar kompensai dan kepuasan kerja, ialah seperti kemampuan daya beli masyarakat, ketertarikan pada model mobil yang dipasarkan, kemudahan pembiayaan dan regulasi pemerintah.

\section{REFERENSI}

Alfaidah, Fitria. (2007). Pengaruh Kepuasan Kerja Karyawan terhadap Produktivitas Kerja pada Koperasi Agro Niaga Jabung Malang. http://lib.uin-malang.ac.id

Almigo, Nuzep. (2004). Hubungan Antara Kepuasan Kerja dengan Produktivitas Kerja Karyawan. Jurnal PSYCHE, Volume 1, Nomer 1.

Black, Sandra E., et all.(2004). How Workers Fare When Employers Innovate. Industrial Relations, vol. (43(1), pp. 44-66.

Ekonugroho, M. Wildan. (2008). Analisis Pengaruh Kepuasan Kerja dan Motivasi Kerja Terhadap Produktivitas Kerja Pegawai Sekretariat Jenderal Departemen Energi dan Sumber Daya Mineral. http://core.kmi.open.ac.uk

Futrell, Charles M. (2001). Sales Management: Teamwork, Leadership, and Technology (Edisi 6) Texas: Harcourt College Publishing.

Gaikindo (Gabungan Industri Kendaraan Bermotor Indonesia). www.gaikindo.or.id

Ghozali, Imam. (2005). Aplikasi Analisis Multivariat dengan Menggunakan SPSS. Semarang: Universitas Diponegoro Press. 
Greenberg, Jeraldand Robert Baron. (2003). Behavior in Organizations (Understanding and Managing the Human Side of Work ). Eight edition, Prentice Hall.

Hariandja, Marihot Tua Efendi. (2002). Manajemen Sumber Daya Manusia. Jakarta: Grasindo.

Ipkoni, Linda Prasepti. (2006). Analisis Pengaruh Kompensasi dan Kondisi Kerja Terhadap Kinerja Karyawan dengan Motivasi sebagai Variabel Pemoderasi (Studi pada Karyawan Bagian Produksi PT. Karga Bayu Persada Sukoharjo). Universitas Negeri Sebelas Maret, Fakultas Ekonomi.

Mangkunegara, AA. Anwar Prabu. (2000). Manajemen Sumber Daya Manusia Perusahaan. Bandung : Remaja Rosdakarya.

Sinungan, Muchdarsyah. (2005). Produktivitas Apa dan Bagaimana. Jakarta: Bumi Aksara.

Muchdarsyah, Sinungan. (2005) Produktivitas Apa dan Bagaimana, Jakarta: Bumi Aksara.

Mustikawati, Novi. (2006). Pengaruh Pemberian Kompensasi dan Motivasi Kerja terhadap Efektifitas Kerja Karyawan Bagian Non Operasional di PT Batik Keris Sukoharja. http://digilib.uns.ac.id

Naibaho, Togar. (2008). Pengaruh Kompensasi Dan Kepuasan Kerja terhadap Produktivitas Kerja Karyawan Pada PT. Casa Woodworking Industry Medan. http://researchgate.net

Rapang, Yuniarti Tandi. (2005). Pengaruh Kompensasi terhadap Produktivitas Kerja Karyawan pada PT. Petra Jaya Lestari (Menurut Persepsi Karyawan). http:// repository.widyatama.ac.id

Rivai, Veithzal dan Jauvani Sagala. (2009). Manajemen Sumber Daya Manusia untuk Perusahaan. Dari Teori ke Praktik. Jakarta: PT Raja Grafindo Persada.

Robbins, Stephen P. (2003). Perilaku organisasi. Jakarta: PT. Indeks Kelompok Gramedia.

Sedarmayanti (2001). Sumber Daya manusia dan Produktivitas Kerja Bandung: Mandar Maju.

Setiadi, Dedi. (2009). Pengaruh Kepuasan kerja Terhadap Produktivitas Kerja Karyawan Percetakan Iqro’Angkatan Muda Masjid dan Mushola Kotagede Yogyakarta. http://digilib.uin-suka.ac.id

Sutojo, Siswanto. (2008). Good Corporate Governance. Jakarta: PT Damar Mulia Pustaka. http://www.otomotif.kompas.com/read/2013/01/11/6126/2012.

Umam, Khaerul. (2010). Perilaku Organisasi. Bandung: CV Pustaka Setia.

Umar, Husein. (2005). Riset Sumber Daya Manusia dalam Organisasi. Jakarta: Penerbit PT Gramedia Pustaka Utama. 
